\title{
Comprehensive study of the mountainous lake sediments in relation to natural and anthropogenic processes and time (Mały Staw Lake, Poland)
}

\author{
Katarzyna Szarlowicz $^{1}$ (D) Witold Reczynski ${ }^{2}$ - Agnieszka Czajka ${ }^{3}$ - Barbara Spyt ${ }^{3}$. \\ Grzegorz Szacilowski ${ }^{1}$
}

Received: 17 March 2017 / Accepted: 7 November 2017 / Published online: 17 November 2017

(C) The Author(s) 2017. This article is an open access publication

\begin{abstract}
The Sudety Mts. form a chain of mountains in the South of Poland and during the last 200 years were subjected to strong industrial and agricultural pressure. The records of these human-induced changes are stored in natural archives like lake sediments. For the comprehensive study, three sediment cores taken from Mały Staw Lake (Sudety Mts.) were analyzed for the concentration of $\mathrm{K}, \mathrm{Na}, \mathrm{Mn}, \mathrm{Fe}, \mathrm{Cu}, \mathrm{Mg}, \mathrm{Zn}$, $\mathrm{Cd}, \mathrm{Cr}, \mathrm{Ni}, \mathrm{Pb}$ and radioactivity of ${ }^{137} \mathrm{Cs}$ and ${ }^{210} \mathrm{~Pb}$. As a result of the studies, the bathymetry map was developed and the sources of solid material supplied to the lake were identified. The geochronology studies of the cores were performed using ${ }^{210} \mathrm{~Pb}$ method, to evaluate model of time changes in the sediment. Radioactivity of ${ }^{210} \mathrm{~Pb}_{\text {uns }}$ (determined indirectly by ${ }^{210} \mathrm{Po}$ ) ranged from $1051 \pm 64$ to $12 \pm 8 \mathrm{~Bq} \mathrm{~kg}^{-1}$. The ${ }^{137} \mathrm{Cs}$ radioactivity was determined directly by gamma spectrometry and varied from $525 \pm 37 \mathrm{~Bq} \mathrm{~kg}^{-1}$ for top layers to $9.80 \pm 5.40$ $\mathrm{Bq} \mathrm{kg}{ }^{-1}$ for the bottom of the core. Two characteristic peaks of ${ }^{137} \mathrm{Cs}$ radioactivity related to the global fallouts after nuclear weapons testing and the Chernobyl accident were observed and used to confirm ${ }^{210} \mathrm{~Pb}$ dating method. Chemometrics analysis of the chosen metal's concentrations combined with
\end{abstract}

Responsible editor: Philippe Garrigues

Katarzyna Szarlowicz

szarlowi@agh.edu.pl

1 AGH University of Science and Technology, Faculty of Energy and Fuels, al. A. Mickiewicza 30, 30-059 Krakow, Poland

2 AGH University of Science and Technology, Faculty of Material Science and Ceramics, al. A. Mickiewicza 30,

30-059 Krakow, Poland

3 University of Silesia, Faculty of Earth Sciences, ul. Będzińska 60, 41-200 Sosnowiec, Poland sample dating showed distinct imprint of human activity on the studied area.

Keywords Geochronology · Radionuclides · Heavy metals · Bathymetry $\cdot$ Environmental changes

\section{Introduction}

Generally, the sediments consist of particles that have been transported by air, water, or glaciers from the sites of their origin in a terrestrial environment and have been deposited on the river, lake, or ocean bottom. The chemical composition of the sediments mainly depends on the geological structure, geomorphology, morphometry (concerning lakes), and climatic conditions. Undoubtedly, the location of the catchment or lake has an extensive impact on the sediments' composition (Noges et al. 1999; Last and Smol 2001). Besides, sediments contain toxins including heavy metals, organic compounds, radionuclides, etc. So, they constitute natural repositories for different kind of contaminants and play important role in the distribution of toxic substances in the aquatic ecosystems (Sandor et al. 2001; de Deckere et al. 2011; Grba et al. 2016).

There are two main sources of toxins: natural, and those related to human activity. Radioactivity is an integral part of the environment. Radionuclides are found naturally in each part of the environment as water, soil, sediments, and air. Among natural radionuclides, ${ }^{210} \mathrm{~Pb}$ radioisotope can be distinguished. It is a long-lived ( $T_{1 / 2}=22.3$ years) radionuclide belonging to the uranium ${ }^{238} \mathrm{U}$ radioactive chain (Appleby 2008). Special attention is attributed to the radionuclides which enter the environment in an uncontrolled way. In this respect, the distribution of ${ }^{137} \mathrm{Cs}$ can be considered. This artificial radionuclide was introduced into the environment in a huge amount during nuclear weapon tests (1945-1965) and was emitted to the 
atmosphere during the Chernobyl accident (1986) (UNSCEAR 2000). Fallout from ${ }^{137} \mathrm{Cs}$ and ${ }^{210} \mathrm{~Pb}$ have been widely used to establish the chronology of sediment cores collected from various aquatic systems (McCall et al. 1984; Ritchie and McHenry 1990; Walling and He 1992; Aycik et al. 2004; Klaminder et al. 2012; Szczepanska et al. 2012).

Considering the presence of metals (including heavy metals) in the environment, it should be noted that the natural cycle of trace elements is characterized by a certain balance between the amount of the element released by the geochemical processes taking place at the Earth's surface, and the amount of element bounded in geological formations. In contrast, the elements emitted to the environment as a result of human activity (industry, transport, agriculture) form the risk of losing the chemical balance in biosphere, if introduced in excessive amount (Dube et al. 2001; Lofrano et al. 2016).

In most cases, the sediments' sampling from the mountain lakes is challenging but their analysis forms valuable contribution to our knowledge of the environment, not only in local but also in regional scale. Especially, complex analysis of the sediments using various scientific approaches can provide interesting information about the water ecosystem. On one hand, sediments can be used for estimation of the state of the water ecosystem (Teuchies et al. 2011; Guzman et al. 2013; Hamerlik et al. 2016). On the other hand, they are often used for studying history of environmental contamination as well as climate and environmental changes (Smol et al. 1991; Bitusik et al. 2009; Ma et al. 2013; Szarlowicz et al. 2013).

In this study, the analytical, radiochemical, sedimentological, and geomorphological methods were used in order to determine changes of the sediments collected from the Maky Staw Lake (Sudetes). The Mały Staw Lake $\left(50^{\circ} 45^{\prime} \mathrm{N}, 15^{\circ} 42^{\prime} \mathrm{E}\right)$ is interesting due to the following reasons: it is localized in the unique Sudety mountains and surrounded by the steep slopes of over $200 \mathrm{~m}$ high; hydrological and meteorological conditions in the area are well defined; reference information concerning geology, composition and properties of rocks and soils, as well as human activity in the past 200 years is also well documented; and last but not least - no such research have ever been undertaken. The aims of the study included determination of the following: the bathymetric survey, identification of the potential sources of material transported to the lake, estimation of the age and sedimentation rate of each layer of the sediments' cores by use of the ${ }^{210} \mathrm{~Pb}$ and ${ }^{137} \mathrm{Cs}$ methods, and determination of the concentration of chosen metals with identification of their origin.

\section{Study area-the Sudetes and the Maly Staw Lake - general information}

The Sudety mountain range is the highest part of the Czech Massif. It stretches from eastern Germany along the northern border of the Czech Republic to south-western Poland. The
Sudetes are a typical example of the horst mountains and their geological structure is highly diversified. The highest part of this old and eroded chain of mountains is the Karkonosze Mts., reaching 1602 m a.s.l. at Mt. Snieżka. The Karkonosze massif is built mainly of granites in which the Mały Staw cirque was created in Pleistocene. The Mały Staw Lake is a cirque, postglacial lake and it is situated in the Polish Karkonosze National Park (Fig. 1). The bottom of the Mały Staw lake lies at an altitude of $1183 \mathrm{~m}$ a.s.l. The lake has area of 2.8 ha and $756 \mathrm{~m}$ of coastline. The Maky Staw Lake is a flow-through lake, drained by Lomnica River, and the Mały Staw cirque is surrounded by steep granite walls of Smogornia and Snieżka massifs. The surrounding $200 \mathrm{~m}$ high walls are cut by few couloirs. Weathered granites of the Karkonosze create gravely and sandy grains, which are easily transported down by gravitation, water, avalanches, or debris flows. The weathered mineral material in favorable conditions creates a debris flows. There are 16 active debris flows in the Maky Staw cirque but none of them reaches the Lake (Jahn 1985; Parzoch et al. 2007). Some valuable information about the historical changes of the lake biota were determined by means of paleobiological research. These revealed, despite climatic factors, also influence of chemical factors like strong dependence of life in the lake on the water body $\mathrm{pH}$ (Sienkiewicz et al. 2006).

\section{Methods}

\section{Bathymetry}

The depth of Mały Staw Lake was measured by means of Lowrance HDR-5 with a $50 / 200-\mathrm{kHz}$ transducer. The Lowrance depth sounder is equipped with a built-in GPS which allows for the logging of depth and co-ordinate data at the same time. Bottom depth measurements were taken multiple times per second along the logging paths. The obtained data set is composed of depth measurements and the associated GPS co-ordinates. The final map was generated by means of ArcGis instruments. The bathymetric map is based on depth points from echo sounder measurements. They were interpolated to produce a quantitative map using the Inverse Distance Weighting (IDW) method.

\section{Sampling}

The sediments' samples were collected during scientific survey in 2013. Three sediments' cores were sampled using Limnos gravity corer (sampler consisted of a set of $1 \mathrm{~cm}$ high rings of $10 \mathrm{~cm}$ diameter). Sediments' cores were collected at three different depths: MS1-2 m $\left(15^{\circ} 42^{\prime} 1.5^{\prime \prime} \mathrm{E} 50^{\circ} 44^{\prime} 53.3^{\prime \prime} \mathrm{N}\right)$,

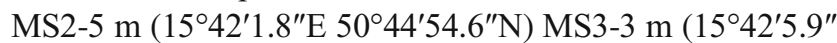
E $50^{\circ} 44^{\prime} 54.9^{\prime \prime} \mathrm{N}$ ) (Fig. 1). The cores were sliced to $1 \mathrm{~cm}$ layers in situ, and packed into polyethylene vessels. The top 
Fig. 1 Location of the studied lake

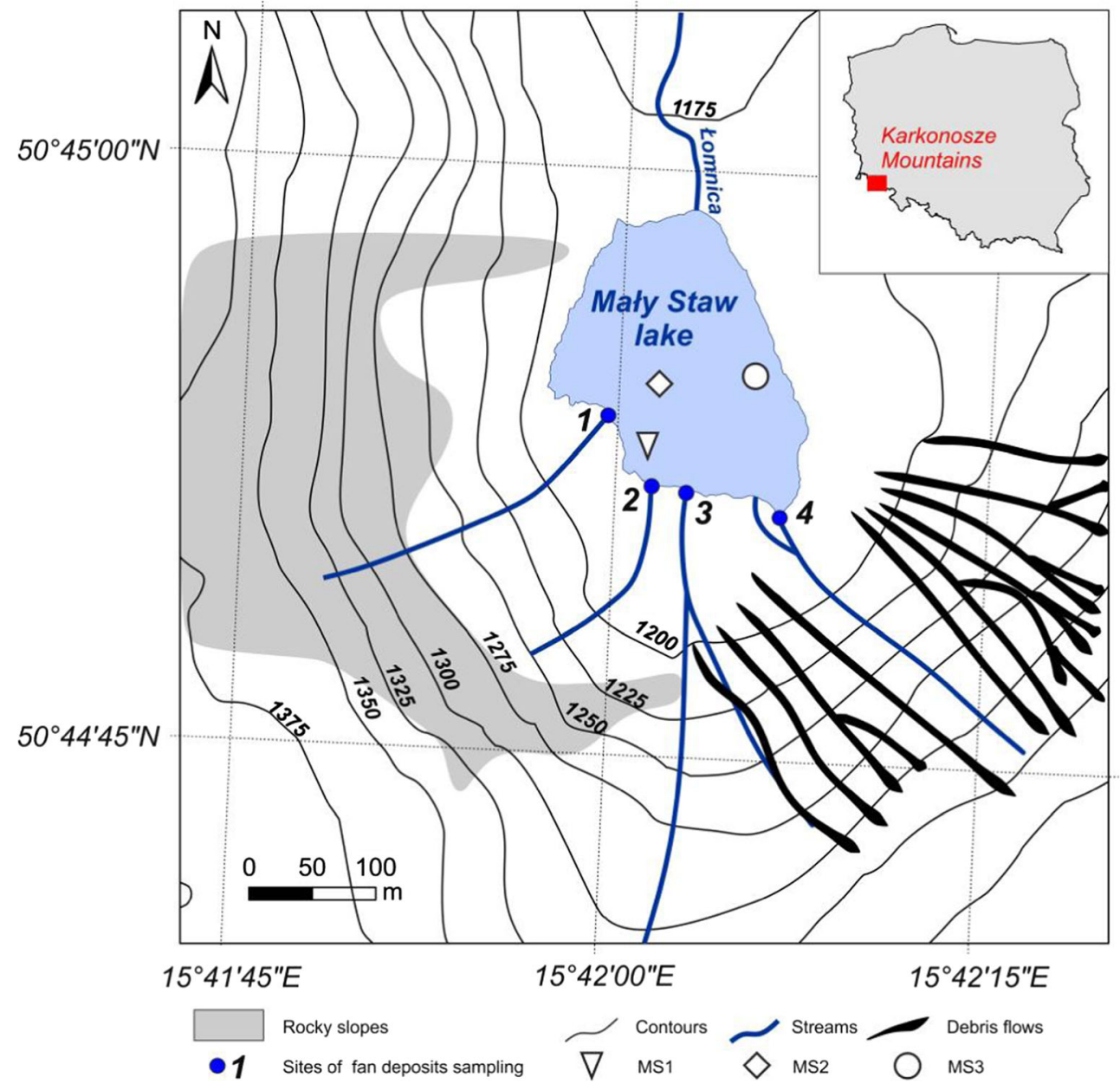

sediments' layers were of low density, while moving to the bottom layers of the core, density increased.

The sediment samples were also taken from four alluvial fans entering the Mały Staw Lake (Fig. 1).

\section{Granulometric analysis of fans deposits}

The samples of sediments originating from the weathering granite massif surrounding the lake were taken from four alluvial fans entering the Mały Staw Lake. Samples were airdried before the granulometric analysis. To determine the percentage of different grain sizes, the granulometric analysis of sediments was performed involving a nested column of sieves placed in a mechanical shaker. For separation of fractions, the sieves with openings of $8,4,2,1,0.5,0.25,0.125$, and $0.063 \mathrm{~mm}$ were used.

\section{${ }^{210} \mathrm{~Pb}$ and ${ }^{137} \mathrm{Cs}$ chronologies}

The age of sediments was estimated for the deepest MS- 2 core. In this sediment's core, the metals' concentrations were also determined. In all sediments' cores, the distribution of cesium radioactivity was measured. Such measurements do not require laborious radiochemical procedure and are valuable in interpretation of the scale of artificial radionuclide contamination.

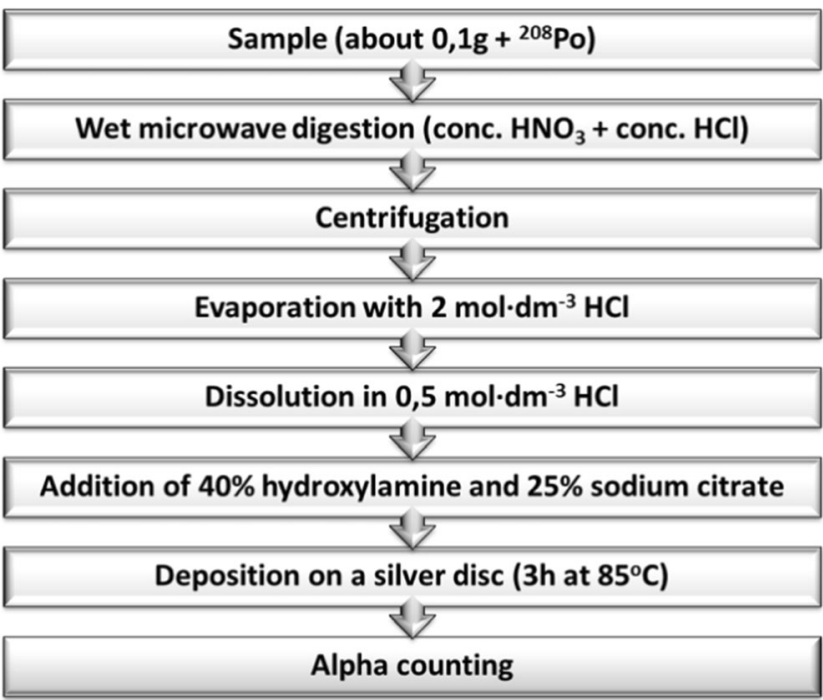

Fig. 2 Scheme of radiochemical procedure of polonium determination 
Table 1 Instrumental parameters of the elements quantitative determination

\begin{tabular}{|c|c|c|c|c|}
\hline \multirow[t]{2}{*}{ Element } & \multirow[t]{2}{*}{ Technique } & \multicolumn{2}{|c|}{ Optical parameters } & \multirow[t]{2}{*}{ Description } \\
\hline & & Lamp type & Wavelength $[\mathrm{nm}]$ & \\
\hline K & AES & HCL & 766.5 & Air-acetylene flame, standard conditions \\
\hline $\mathrm{Na}$ & AES & HCL & 589.0 & Air-acetylene flame, standard conditions \\
\hline $\mathrm{Cu}$ & F AAS & HCL & 324.8 & Air-acetylene flame, standard conditions \\
\hline $\mathrm{Fe}$ & F AAS & HCL & 248.3 & Air-acetylene flame, standard conditions \\
\hline $\mathrm{Mg}$ & F AAS & HCL & 285.2 & Air-acetylene flame, standard conditions \\
\hline $\mathrm{Mn}$ & F AAS & HCL & 279.5 & Air-acetylene flame, standard conditions \\
\hline $\mathrm{Zn}$ & F AAS & HCL & 213.9 & Air-acetylene flame, standard conditions \\
\hline $\mathrm{Cd}$ & ET AAS & EDL & 228.8 & $\begin{array}{l}\text { Pyro/platform tube, Deuterium Lamp } \\
\text { background correction }\end{array}$ \\
\hline $\mathrm{Cr}$ & ET AAS & HCL & 357.9 & $\begin{array}{l}\text { Pyro/platform tube, Zeeman background } \\
\text { correction }\end{array}$ \\
\hline $\mathrm{Ni}$ & ET AAS & HCL & 232.0 & $\begin{array}{l}\text { Pyro/platform tube, Zeeman background } \\
\text { correction }\end{array}$ \\
\hline $\mathrm{Pb}$ & ET AAS & EDL & 283.3 & $\begin{array}{l}\text { Pyro/platform tube, Deuterium Lamp } \\
\text { background correction }\end{array}$ \\
\hline
\end{tabular}

Dating of sediment was established by applying the Constant Rate of Supplying (CRS) model to the measured ${ }^{210} \mathrm{~Pb}_{\text {uns }}$ data (Appleby and Oldfield 1978; Appleby 2001).
The radioactivity of unsupported ${ }^{210} \mathrm{~Pb}$ was calculated from total radioactivity of ${ }^{210} \mathrm{~Pb}$ by subtraction of the supported radioactivity. The supported radioactivity was determined by
Fig. 3 Map showing locations of track lines along which depth data were collected

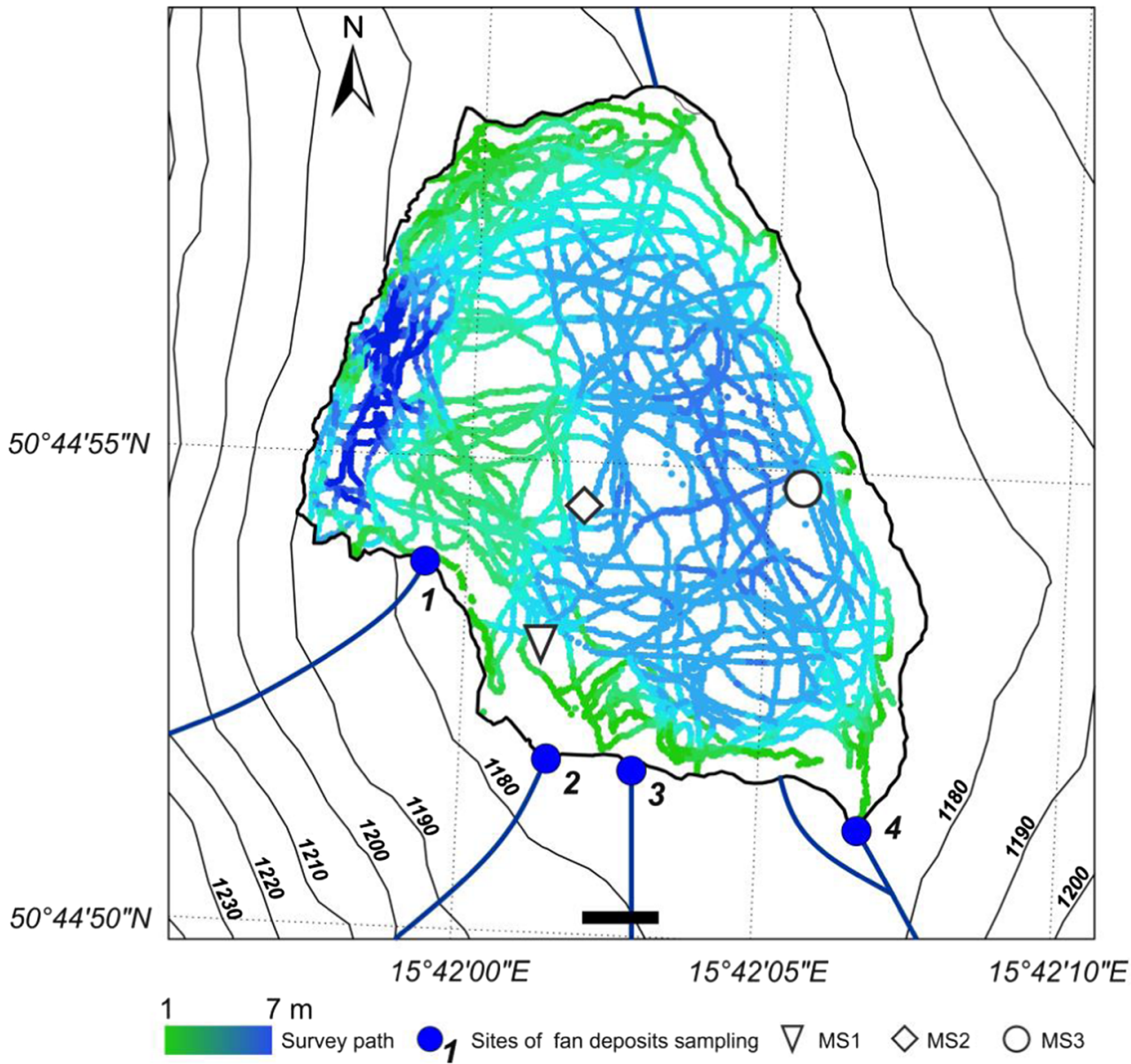


measurements made on old sediments. Radioactivity of the sediments in the deepest part of the core is ascribed to the supported ${ }^{210} \mathrm{~Pb}$ radioactivity (the oldest sediments contain no unsupported ${ }^{210} \mathrm{~Pb}$ ). It uses the equation presented in Szarlowicz et al. (2013) and the age and the sedimentation rate of each layer were estimated. Usually ${ }^{210} \mathrm{~Pb}$ dating should be confirmed by another method, so ${ }^{137} \mathrm{Cs}$ was used as a tool for ${ }^{210} \mathrm{~Pb}$ validation. As the presence of ${ }^{137} \mathrm{Cs}$ at elevated levels was known to occurred during 1963 (maximum of global fallout) and 1986 (fallout of Chernobyl accident), the observed maxima in ${ }^{137} \mathrm{Cs}$ level in the sediment cores could have been ascribed to these incidents and correlated with the depth of sediment (Klaminder et al. 2012).

\section{${ }^{210} \mathrm{~Pb}$ measurement}

To determine lead, the alpha spectrometry method was used. Alpha spectrometry requires radionuclides separation. ${ }^{210} \mathrm{~Pb}_{\text {tot }}$ in the sediment samples was determined by carrying out a spontaneous deposition of ${ }^{210} \mathrm{Po}$ (daughter radionuclide in radioactive equilibrium with its parent ${ }^{210} \mathrm{~Pb}$ ) on the surface of a silver disc (Flynn 1968). First, polonium in all analyzed samples was determined. The alpha sources were measured using an alpha spectrometer (Canberra model 7401, equipped with Passivated Implanted Planar Silicon (PIPS) detector active area $450 \mathrm{~mm}^{2}$, efficiency $34 \%$ ). A single measurement lasted 3 days. After about 6 months, a sufficient amount of new ${ }^{210}$ Po had been grown in the sample; a new deposition was carried out. In Fig. 2, the scheme of the procedure is shown. Generally, the procedure consists of the following: sample digestion, evaporation, sample preparation for deposition, deposition. All analyses were carried out with ${ }^{208} \mathrm{Po}$, a radiotracer used to control efficiency of the procedure. Known radioactivity of polonium from two depositions enabled calculation of lead total radioactivity (Szarlowicz et al. 2013).

\section{${ }^{137}$ Cs measurement}

The sediment core samples were analyzed for ${ }^{137} \mathrm{Cs}\left(\mathrm{T}_{1 / 2}=\right.$ 30.07 years) at $661.6 \mathrm{keV}$ by means of gamma spectrometry. Gamma measurement was conducted on a low background, high purity coaxial germanium detector (Canberra, model GC2020, relative efficiency 20\%) coupled with a multichannel analyzer. The counting system was calibrated for energy and efficiency. The energy calibration was carried out with known radionuclides of varying gamma energies
Fig. 4 Bathymetric map of the Mały Staw Lake

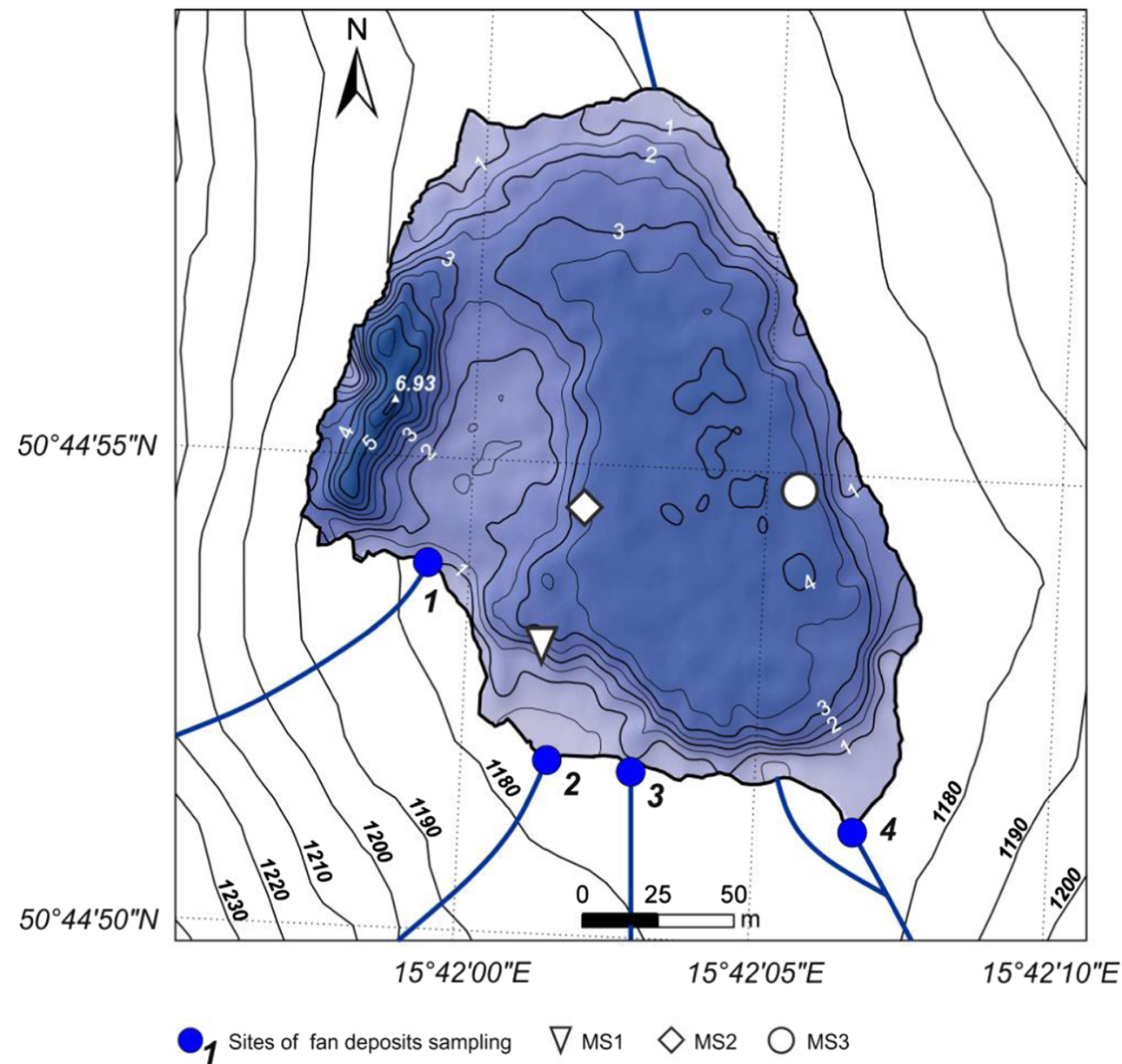




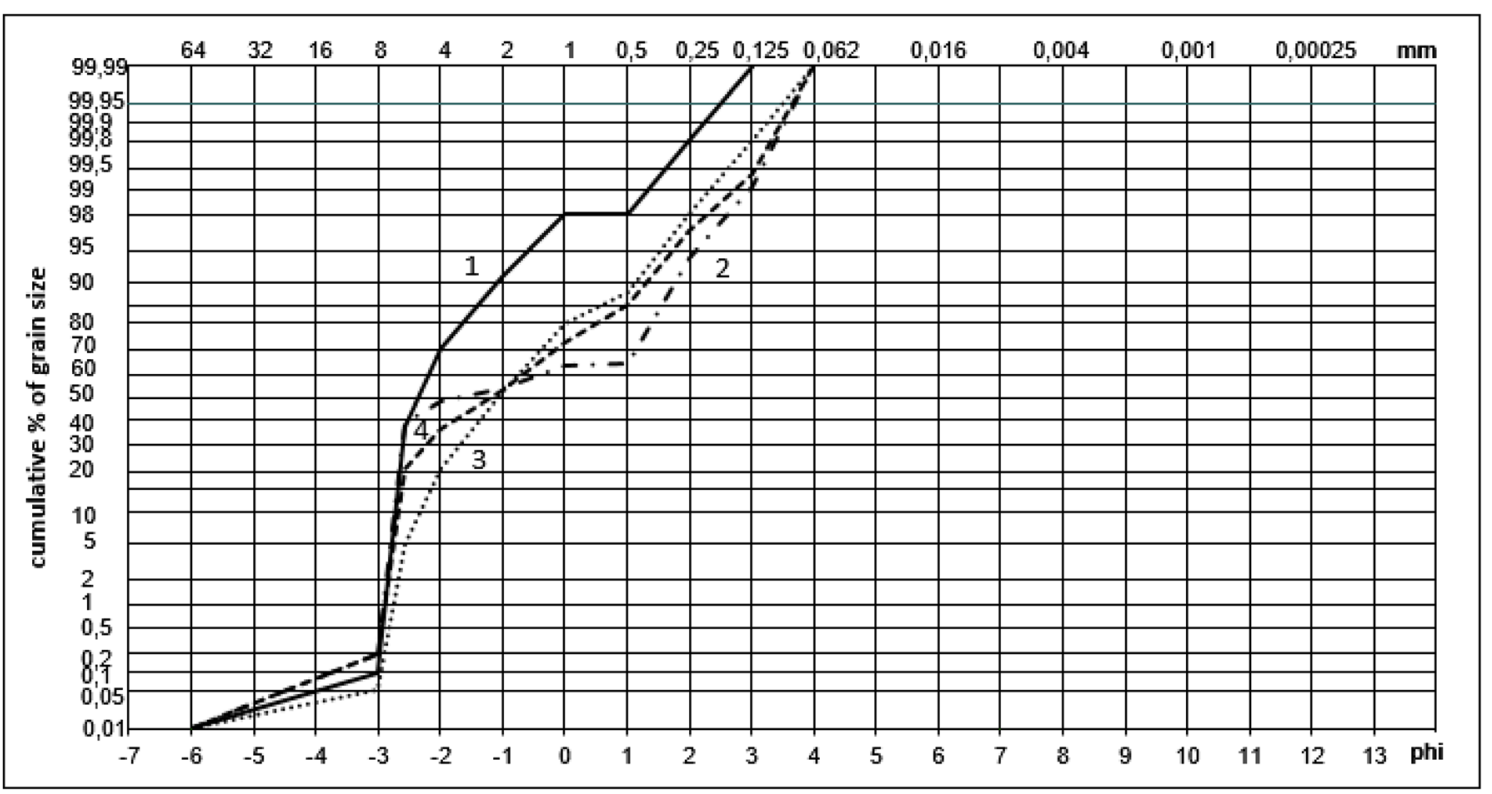

Fig. 5 Granulometric curves of alluvial fans deposits

(Spectrum Techniques, ${ }^{133} \mathrm{Ba},{ }^{137} \mathrm{Cs},{ }^{60} \mathrm{Co},{ }^{65} \mathrm{Zn}$ ). The efficiency calibration was done using the reference material (IAEA-447) supplied by the International Atomic Energy Agency (IAEA, Vienna, Austria) according the procedure proposed by Misiak et al. (2011). The samples were measured in the standardized polyethylene vessels (volume $120 \mathrm{~cm}^{3}$, cylindrical $-5 \mathrm{~cm}$ diameter and $7 \mathrm{~cm}$ high), for 3 days. All radioactivity measurements reported, refer to dry mass of the sample, and were calculated for the day of sampling.

\section{Heavy metals determination}

Quantitative determination of metals in the sediments core samples was performed after the following sample preparation procedure. The samples were air-dried, sieved, powdered, and homogenized. Then, the samples were wet digested (the single sample weight was about $0.1 \mathrm{~g}$ ) using the mixture of nitric acid $(65 \%)$ and hydrogen peroxide (30\%) (Suprapure, Merck, Germany) in an Anton Paar Multiwave 3000 (Switzerland) microwave system. After digestion, the volume of reagents was reduced by evaporation on a hot plate and the solution was filtered into a 10-ml volumetric flask. Simultaneously, the blank samples were prepared to control possible samples contamination. Each of the processed sediments' sample was digested in two replicates.

Sodium and potassium concentrations were determined using the flame photometry method (AES), copper, magnesium, iron, manganese, and zinc were determined by means of the flame technique of atomic absorption spectrometry method (F AAS), while nickel, cadmium, lead, and chromium by means of the electrothermal AAS. Analyses were performed using the Perkin Elmer spectrometer Model 3110 (AES, F AAS, USA) equipped with the graphite furnace Perkin
Elmer HGA 600 (ET AAS, USA) and Perkin Elmer spectrometer Model 4100 ZL (Germany) (used in $\mathrm{Cr}$ and Ni determinations). The analytical procedure was optimized in respect to the sample preparation and quantitative determination of the elements. In Table 1, the techniques used and basic instrumental parameters are listed. Accuracy of the determinations was checked by analysis of the certified reference material, River Sediment CRM 320 (the analytes - Cd, Cr, $\mathrm{Cu}, \mathrm{Ni}, \mathrm{Pb}, \mathrm{Zn}$ ). Good agreement was found in respect to the elements' certified concentration values.

\section{Results and discussion}

The bathymetric survey provided a detailed map of the Mały Staw Lake floor topography. Track lines along which the collected depth data are presented in Fig. 3. Each point in the map

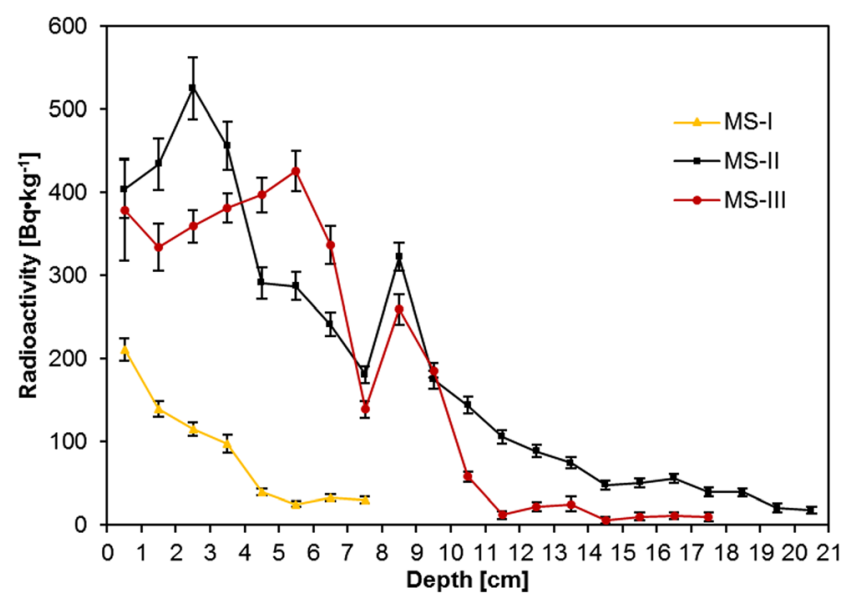

Fig. 6 Changes of ${ }^{137} \mathrm{Cs}$ radioactivity in the sediment cores 


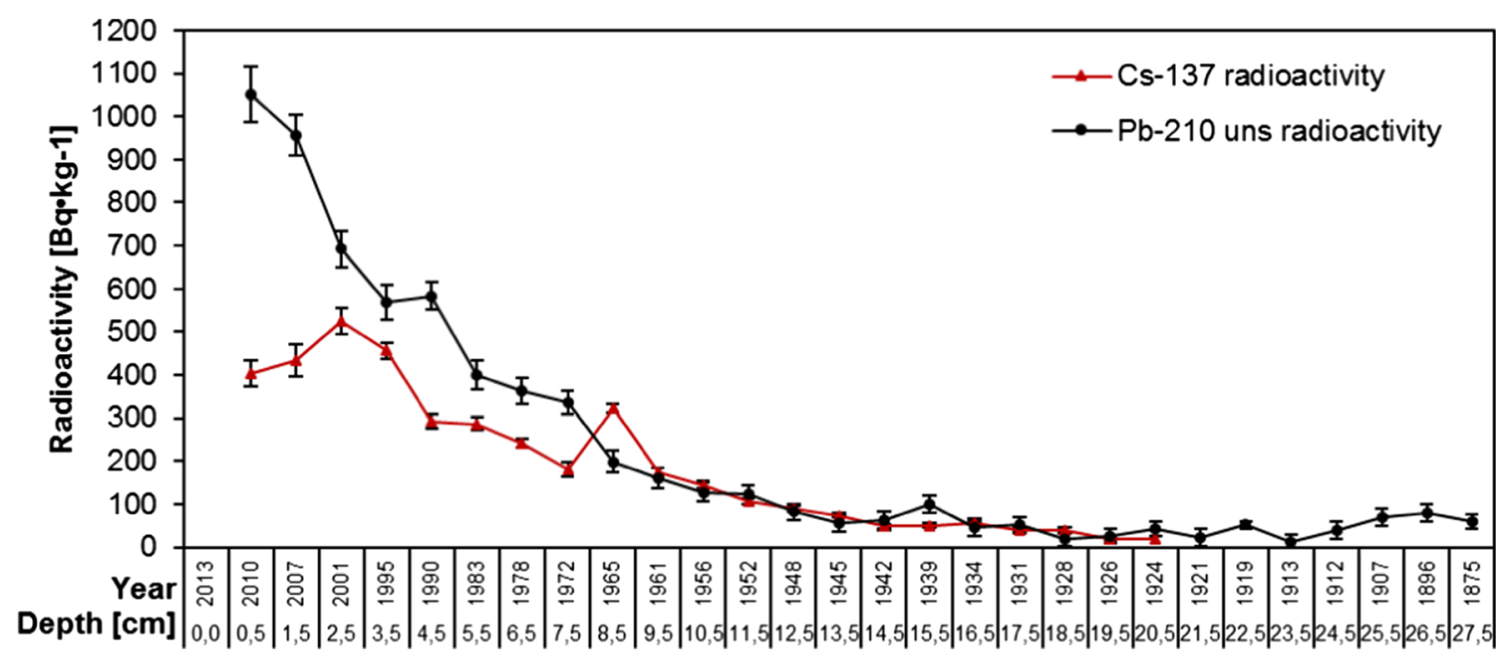

Fig. 7 Depth-age model based on ${ }^{210} \mathrm{~Pb}$ and ${ }^{137} \mathrm{Cs}$ geochronology

reflects one measurement point in the field. The maximum depth, located in the west part of the Lake, is $6.93 \mathrm{~m}$. A similar value was given by Komar (1949).

The average depth of the lake is $3.4 \mathrm{~m}$ and the lake bottom is divided into two basins: the deeper, narrow west basin and the shallower west basin. We did not examine the character of the ridge dividing the lake. According to the previous research, it may be a remnant of moraine (Piasecki 1958).

Along the south shore, four alluvial cones are clearly visible in the plotted bathymetric map (Fig. 4). Fans 1, 2, and 4 go under the water lake to the depths of approximately $1.5,3.5$, and $2 \mathrm{~m}$, respectively. Most deposits of fan number 3 are deposited at the land, as the slope of the last reach of the stream transporting the material is relatively low.

The sediments of debris flows are poorly sorted and the finer material is periodically washed out of the debris flow deposits by water from melting snow or from precipitation. This material creates alluvial fans partially entering the lake and the finest grains are deposited at the lake bottom. Łomnica is the only permanent (except in winter) watercourse supplying the Mały Staw Lake with water and sediments. In Fig. 5, the granulometric curves of alluvial fans deposits are shown. Fan number 1 consists mainly of gravel, and numbers 2, 3, and
4 of sandy gravel. Deposits of fan number 2 are poorly sorted ( standard deviation $=2.25$ ) while deposits of fans 1,3 , and 4 are better sorted (standard deviation is $1.07,1.36$, and 1.85, respectively). The reason for these differences may be the fact that fan number 2 is created by weathered material, transported down by the shortest stream among four discussed, which creates less possibility to sort the fractions during transportation.

The ${ }^{137} \mathrm{Cs}$ radioactivity was measured and varied in the range from $9.80 \pm 5.40$ to $525 \pm 37 \mathrm{~Bq} \mathrm{~kg}^{-1}$. Vertical distribution of ${ }^{137} \mathrm{Cs}$ in the sediment cores of the Maly Staw Lake is presented in Fig. 6. Despite the fact that the sampling points were located in different regions of the lake (and also differing in depth), the ${ }^{137} \mathrm{Cs}$ distribution is quite similar. In each sediment core, cesium radioactivity is at the highest level in the uppermost sediment layer and decreases with depth down the core. The highest value of ${ }^{137} \mathrm{Cs}$ radioactivity in the top layer of the sediments relates to delivery of this radionuclide from the soil surrounding lake and Łomnica slopes. The shortest of the sediment cores is different comparing to the other two. This sediment core was located in the shallow part of the reservoir where the coarse grain size material and stones are deposited. Such conditions do not favor ${ }^{137} \mathrm{Cs}$ sorption.
Fig. 8 Changes of sedimentation rate in the studied period of time

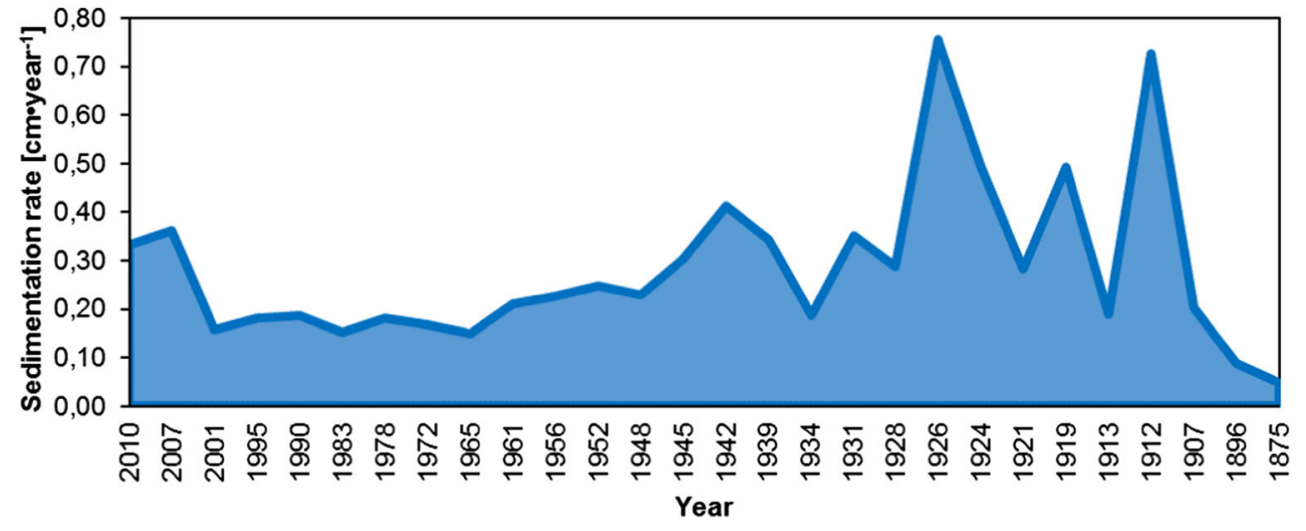


Table 2 Concentrations of $\mathrm{K}$, $\mathrm{Mg}, \mathrm{Fe}, \mathrm{Mn}$, and $\mathrm{Na}$ in the sediments' core samples of the Mały Staw Lake in reference to the layer depth

\begin{tabular}{|c|c|c|c|c|c|c|}
\hline Sample $[\mathrm{cm}]$ & Age [years] & $\begin{array}{l}\mathrm{K} \\
{\left[\mu \mathrm{g} \mathrm{g}^{-1}\right] \pm \mathrm{SD}}\end{array}$ & $\mathrm{Mg}$ & $\mathrm{Fe}$ & Mn & $\mathrm{Na}$ \\
\hline 1 & 2010 & $1022 \pm 5$ & $1432 \pm 11$ & $8027 \pm 64$ & $90 \pm 1$ & $79 \pm 1$ \\
\hline 2 & 2007 & $3649 \pm 240$ & $1925 \pm 96$ & $9977 \pm 548$ & $108 \pm 7$ & $237 \pm 7$ \\
\hline 4 & 1995 & $3853 \pm 16$ & $2076 \pm 48$ & $10,535 \pm 428$ & $118 \pm 2$ & $221 \pm 1$ \\
\hline 6 & 1983 & $3823 \pm 117$ & $2147 \pm 32$ & $10,683 \pm 256$ & $117 \pm 3$ & $235 \pm 40$ \\
\hline 8 & 1972 & $3727 \pm 122$ & $2212 \pm 43$ & $10,810 \pm 156$ & $114 \pm 3$ & $202 \pm 20$ \\
\hline 10 & 1961 & $3532 \pm 189$ & $2325 \pm 25$ & $11,205 \pm 219$ & $120 \pm 3$ & $197 \pm 54$ \\
\hline 12 & 1952 & $3911 \pm 110$ & $2530 \pm 204$ & $12,248 \pm 128$ & $129 \pm 2$ & $195 \pm 8$ \\
\hline 14 & 1945 & $3835 \pm 145$ & $2595 \pm 45$ & $11,955 \pm 556$ & $130 \pm 2$ & $159 \pm 4$ \\
\hline 16 & 1939 & $4152 \pm 152$ & $3315 \pm 19$ & $12,988 \pm 1315$ & $138 \pm 2$ & $184 \pm 3$ \\
\hline 18 & 1931 & $3798 \pm 19$ & $2829 \pm 31$ & $12,075 \pm 116$ & $134 \pm 2$ & $151 \pm 13$ \\
\hline 20 & 1926 & $3258 \pm 13$ & $2942 \pm 8$ & $13,090 \pm 198$ & $126 \pm 1$ & $127 \pm 1$ \\
\hline 22 & 1921 & $4526 \pm 113$ & $2704 \pm 74$ & $12,960 \pm 1580$ & $144 \pm 1$ & $202 \pm 26$ \\
\hline 24 & 1913 & $4037 \pm 250$ & $2744 \pm 117$ & $9338 \pm 2158$ & $138 \pm 2$ & $160 \pm 20$ \\
\hline 26 & 1907 & $4265 \pm 348$ & $2718 \pm 108$ & $13,415 \pm 1558$ & $143 \pm 4$ & $166 \pm 32$ \\
\hline 28 & 1875 & $4301 \pm 204$ & $2590 \pm 101$ & $12,033 \pm 575$ & $140 \pm 1$ & $172 \pm 15$ \\
\hline 30 & - & $4185 \pm 497$ & $2644 \pm 152$ & $11,253 \pm 283$ & $145 \pm 6$ & $156 \pm 33$ \\
\hline 32 & - & $3831 \pm 339$ & $2341 \pm 21$ & $9940 \pm 106$ & $120 \pm 2$ & $137 \pm 22$ \\
\hline 33 & - & $3540 \pm 399$ & $2359 \pm 66$ & $9923 \pm 332$ & $124 \pm 2$ & $117 \pm 13$ \\
\hline
\end{tabular}

Besides, this sediment core is too short to interpret distribution of this radionuclide. In two longer sediment cores, ${ }^{137} \mathrm{Cs}$ radioactivity declines no monotonously with two distinct maxima corresponding to depth ranges 4.5-5.5 and 8.5-9.5 cm. The elevated level of the ${ }^{137} \mathrm{Cs}$ radioactivity corresponds to the nuclear weapon tests (1963) and the Chernobyl accident
(1986) (UNSCEAR 2000). Firstly, the fallout from nuclear weapons tests had an influence on the radioactive contamination level of the environment in Poland. But the main contribution to the growth of the radioactive contamination is ascribed to the Chernobyl accident. Fission products such as ${ }^{137} \mathrm{Cs}$ were moving with the masses of air according to actual

Table 3 Concentrations of $\mathrm{Pb}, \mathrm{Zn}, \mathrm{Cd}, \mathrm{Cu}, \mathrm{Cr}$, and $\mathrm{Ni}$ in the sediments' core samples of the Mały Staw Lake in reference to the layer depth

\begin{tabular}{|c|c|c|c|c|c|c|c|}
\hline $\begin{array}{l}\text { Sample } \\
\text { depth [cm] }\end{array}$ & Age [years] & $\begin{array}{l}\mathrm{Pb} \\
{\left[\mu \mathrm{g} \mathrm{g}^{-1}\right] \pm \mathrm{SD}}\end{array}$ & $\mathrm{Zn}$ & $\mathrm{Cd}$ & $\mathrm{Cu}$ & $\mathrm{Cr}$ & $\mathrm{Ni}$ \\
\hline 1 & 2010 & $206 \pm 1$ & $81.10 \pm 0.50$ & $16.10 \pm 0.60$ & $19.2 \pm 1.3$ & $12.20 \pm 0.50$ & $5.50 \pm 0.40$ \\
\hline 2 & 2007 & $222 \pm 14$ & $85.6 \pm 7.5$ & $26.1 \pm 2.8$ & $24.3 \pm 1.8$ & $19.50 \pm 0.40$ & $7.56 \pm 0.85$ \\
\hline 4 & 1995 & $216 \pm 4$ & $90.3 \pm 1.5$ & $13.00 \pm 0.70$ & $27.2 \pm 0.60$ & $20.00 \pm 0.30$ & $8.00 \pm 0.49$ \\
\hline 6 & 1983 & $224 \pm 14$ & $100.70 \pm 0.50$ & $15.1 \pm 4.2$ & $27.20 \pm 0.60$ & $19.70 \pm 1.2$ & $8.93 \pm 0.31$ \\
\hline 8 & 1972 & $210 \pm 2$ & $108.60 \pm 0.90$ & $18.70 \pm 0.20$ & $25.50 \pm 0.50$ & $19.00 \pm 0.40$ & $9.28 \pm 0.97$ \\
\hline 10 & 1961 & $208 \pm 17$ & $105.3 \pm 1.5$ & $21.60 \pm 0.09$ & $24.00 \pm 0.30$ & $16.10 \pm 0.60$ & $7.62 \pm 0.63$ \\
\hline 12 & 1952 & $201 \pm 8$ & $98.6 \pm 1.6$ & $17.2 \pm 1.5$ & $24.00 \pm 0.80$ & $17.4 \pm 1.5$ & $7.16 \pm 0.17$ \\
\hline 14 & 1945 & $163 \pm 2$ & $82.7 \pm 1.1$ & $13.3 \pm 2.8$ & $22.40 \pm 0.30$ & $15.00 \pm 0.30$ & $6.70 \pm 0.33$ \\
\hline 16 & 1939 & $154 \pm 2$ & $71.21 \pm 0.62$ & $5.72 \pm 0.41$ & $23.10 \pm 0.32$ & $15.70 \pm 0.90$ & $6.49 \pm 0.32$ \\
\hline 18 & 1931 & $155 \pm 2$ & $72.6 \pm 1.7$ & $9.8 \pm 0.2$ & $23.01 \pm 0.70$ & $13.80 \pm 0.21$ & $6.21 \pm 0.54$ \\
\hline 20 & 1926 & $151 \pm 2$ & $61.51 \pm 0.40$ & $9.30 \pm 0.11$ & $19.7 \pm 2.3$ & $12.50 \pm 0.61$ & $5.64 \pm 0.49$ \\
\hline 22 & 1921 & $161 \pm 10$ & $65.7 \pm 0.8$ & $8.0 \pm 0.4$ & $22.8 \pm 0.3$ & $15.41 \pm 0.60$ & $6.92 \pm 0.32$ \\
\hline 24 & 1913 & $150 \pm 6$ & $60.40 \pm 0.61$ & $8.11 \pm 0.40$ & $22.20 \pm 0.41$ & $13.2 \pm 1.0$ & $6.36 \pm 0.03$ \\
\hline 26 & 1907 & $160 \pm 1$ & $67.10 \pm 5.31$ & $7.6 \pm 1.7$ & $22.90 \pm 0.31$ & $14.32 \pm 0.60$ & $6.66 \pm 0.19$ \\
\hline 28 & 1875 & $153 \pm 3$ & $58.20 \pm 0.51$ & $7.20 \pm 0.80$ & $22.50 \pm 0.70$ & $14.0 \pm 1.4$ & $6.01 \pm 0.19$ \\
\hline 30 & - & $158 \pm 4$ & $59.7 \pm 1.7$ & $7.6 \pm 0.2$ & $22.60 \pm 1.01$ & $13.6 \pm 1.5$ & $5.75 \pm 0.25$ \\
\hline 32 & - & $138 \pm 4$ & $52.4 \pm 0.8$ & $7.7 \pm 0.3$ & $18.31 \pm 0.40$ & $12.01 \pm 0.81$ & $5.310 \pm 0.070$ \\
\hline 33 & - & $138 \pm 11$ & $50.60 \pm 0.81$ & $7.2 \pm 1.1$ & $18.06 \pm 0.10$ & $11.00 \pm 0.40$ & $5.17 \pm 0.14$ \\
\hline
\end{tabular}


Table 4 Concentrations ranges, mean values of the analyzed metals concentrations in the core samples of the Mały Staw Lake $\left[\mu \mathrm{g} \mathrm{g}^{-1}\right]$

\begin{tabular}{llll}
\hline Element & Minimal concentration & Maximal concentration & Mean \\
\hline $\mathrm{Fe}$ & 8027 & 13,415 & 11,288 \\
$\mathrm{~K}$ & 1022 & 4526 & 3830 \\
$\mathrm{Mg}$ & 1432 & 3315 & 2485 \\
$\mathrm{Na}$ & 79 & 237 & 176 \\
$\mathrm{Mn}$ & 90 & 145 & 128 \\
$\mathrm{Ni}$ & 5.17 & 9.28 & 6.81 \\
\hline
\end{tabular}

meteorological conditions and then they were depositing on the surface. The highest levels that are observed in the South of Poland are the result of intensive local rainfall occurring in these areas during the Chernobyl accident (Biernacka et al. 2004; Kardas et al. 2011; Isajenko et al. 2012). The obtained results confirmed data collected by a meteorological station located at the Snieżka Mt. Distinct ${ }^{137} \mathrm{Cs}$ radioactivity maxima (Fig. 6), observed between 1959 and 1965 and in 1986, resulted from the aforementioned events (Czerwinski 1995). The cesium radioactivity still decreases as a results of its natural radioactive decay.

The profile of unsupported ${ }^{210} \mathrm{~Pb}$ concentration for the MS2 core is shown in Fig. 7. Radioactivity of ${ }^{210} \mathrm{~Pb}_{\text {uns }}$ was in the range of $12 \pm 8$ to $1051 \pm 64 \mathrm{~Bq} \mathrm{~kg}^{-1}$. Regular decrease of radioactivity of this radionuclide in the discussed sediment core was observed. The radioactivity declines in a stepwise manner. There are some irregularities from $17.5 \mathrm{~cm}$ down the sediment core. Probably, some disturbances and/or sediment mixing occurred. The CRS model was used and the sediment core was dated. The lead dating indicates that $28 \mathrm{~cm}$ of the core represents the past ca 138 years. The results from ${ }^{210} \mathrm{~Pb}$ dating were confirmed by ${ }^{137} \mathrm{Cs}$ studies. Sediments in the depth range 4.5$5.5 \mathrm{~cm}$ correspond to the period 1983-1990 (Chernobyl accident) and those at depths ranging between 8.5 and $9.5 \mathrm{~cm}$ were assigned to the years 1961-1965 (nuclear tests) (Fig. 7).

The deposition time of each sediment layer along the core was different. In the first two layers, it was around 3 years, going to third layer (2001), it was 6 years for $1 \mathrm{~cm}$. Next, in the second half of the twentieth century, this time was estimated between 4 and 7 years for each $1 \mathrm{~cm}$ layer. Going deeper, from
$13 \mathrm{~cm}$ (1948) to $25 \mathrm{~cm}$ (around 1912), deposition time was estimated to be around 3 years per $1 \mathrm{~cm}$ layer. Finally, from $26 \mathrm{~cm}$ (1907) to $28 \mathrm{~cm}$ (1875), it was 5, 11, and 21 years per $1 \mathrm{~cm}$ layer, respectively. The length of deposition time is reflected in the values of the sedimentation rate (Fig. 8). The shorter the deposition time, the higher is the value of sedimentation rate. The average sedimentation rate of the core was estimated to $0.28 \mathrm{~cm} /$ year. There can be indicated periods for which the higher values of sedimentation rate were distinguished. The first one, from 2007 to 2010, corresponded to the period of extraordinary rainfall (the fallout was at the highest level since 2000). In total, 1272-1316 mm of precipitation fall in the studied area (CSO 2008, 2009, 2010, 2011). This resulted in transport of high amounts of solid material, for example with storm water, down the slopes of the surrounding mountains. Considering beginning of the twentieth century (up to 1939), the values of sedimentation rate were at their highest level. This can be explained by the delivery of a huge amount of deposited material in a short time induced by, e.g., avalanches, meteorological situation, or melting snow. The historical records show that in this period of time, rainfall was rather at average level, but in 1913 a heavy rainfall event occurred. Following this, numerous avalanches also occurred and the biggest in the Mały Staw cirque was reported in 1928 (Jahn 1985).

For the first time, in respect to the sediments of the Mały Staw Lake, the chosen metals' concentrations in the collected sediments core samples were determined (Tables 2 and 3). Concentrations of potassium, magnesium, iron, sodium, and manganese were the lowest in the top $1 \mathrm{~cm}$ layer of the sediments' core. The highest concentration of $\mathrm{K}$ was in the layer at $22 \mathrm{~cm}$ (dated to the year 1921) while magnesium in the layer at $16 \mathrm{~cm}$ deep (year 1939). In the layer adjacent to the top one, concentration of sodium was the highest. Considering concentrations of iron and manganese, highest concentrations were found in the layers between 26 and $30 \mathrm{~cm}$ of the core (Table 2).

Regarding concentrations of the other metals, it can be observed that the lowest concentrations of lead, zinc, cadmium, copper, chromium, and nickel were determined in the deepest, oldest layers of the core (depth $32-33 \mathrm{~cm}$ ), the highest in much younger layers dated to years 1972-2007 (layers 2-8 cm) (Table 3).
Table 5 Comparison of the heavy metals' concentrations in the Mały Staw Lake with geochemical background and contamination classification. Concentration values in milligram per kilogram

\begin{tabular}{|c|c|c|c|c|c|c|}
\hline \multirow[t]{2}{*}{ Element } & \multirow{2}{*}{$\begin{array}{l}\text { Mały Staw } \\
\text { Lake (mean) }\end{array}$} & \multirow{2}{*}{$\begin{array}{l}\text { Mały Staw Lake } \\
\text { (maximum) }\end{array}$} & \multirow{2}{*}{$\begin{array}{l}\text { Geochemical } \\
\text { background }\end{array}$} & \multicolumn{3}{|c|}{ Contamination classification } \\
\hline & & & & I class & II class & III class \\
\hline $\mathrm{Cd}$ & 12,5 & 26.1 & $<0.5$ & 1.0 & 3.5 & 6 \\
\hline $\mathrm{Cr}$ & 15.4 & 20 & 6 & 50 & 100 & 400 \\
\hline $\mathrm{Cu}$ & 22.9 & 27.2 & 7 & 40 & 100 & 300 \\
\hline $\mathrm{Pb}$ & 176 & 222 & 15 & 30 & 100 & 200 \\
\hline $\mathrm{Zn}$ & 76.5 & 108.6 & 73 & 200 & 600 & 1000 \\
\hline
\end{tabular}


Fig. 9 Dendrogram presenting similarity of the elements' concentrations variability in the sediments core of the Mały Staw Lake
Dendrogram

Ward's Method,Squared Euclidean

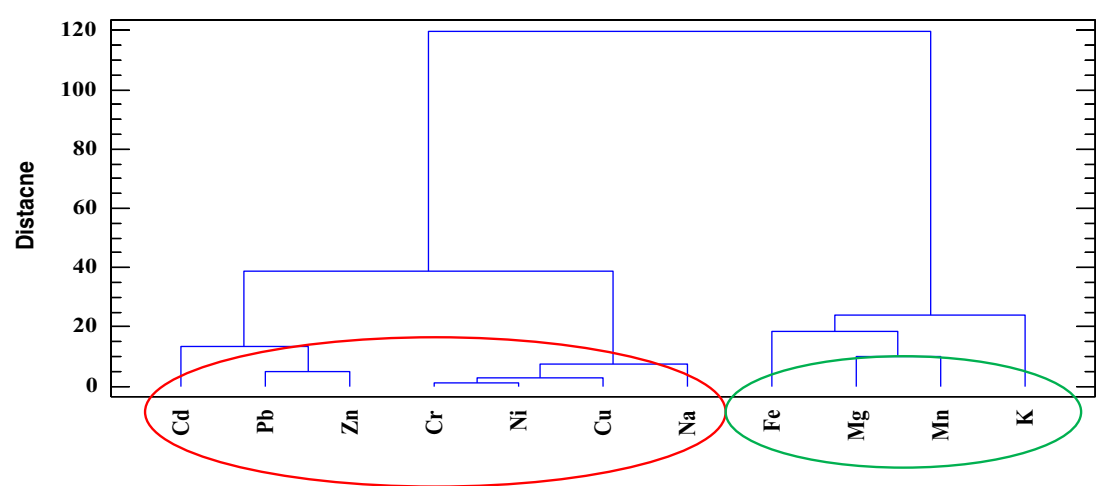

To get the general view on the results concerning metals concentrations in the Mały Staw Lake sediments, some basic statistical analysis of the obtained results is summarized in Table 4.

Sediments contamination degree in general can be classified according to the toxic elements' concentrations into three classes I-clean, II-moderately contaminated, and III-contaminated (Table 5). Also, the sediments quality can be discussed by comparing the obtained specific data to the natural concentration of the elements in the sediments (geochemical background for the Polish lakes' sediments) (Bojakowska and Sokołowska 1998). Out of the five listed elements, only concentration of zinc is close to the geochemical background for Poland. Concentrations of the other heavy metals are substantially higher. On the other hand, if one considers the presented classification, depending on the element, the sediments of the Mały Staw Lake belong to the $\mathrm{I}^{\text {st }}$ class - sediments not contaminated $(\mathrm{Cr}, \mathrm{Cu}$, and $\mathrm{Zn})$ or to the $\mathrm{III}^{\text {rd }}$ class, if $\mathrm{Cd}$ and $\mathrm{Pb}$ concentrations are discussed. Undoubtedly, the latter two elements high concentrations result not only from human activity but also from natural weathering of the mother rock, as the lowest determined concentrations (deepest sediments' layers) were still several times (around 10 times) higher than the geochemical background for Poland.

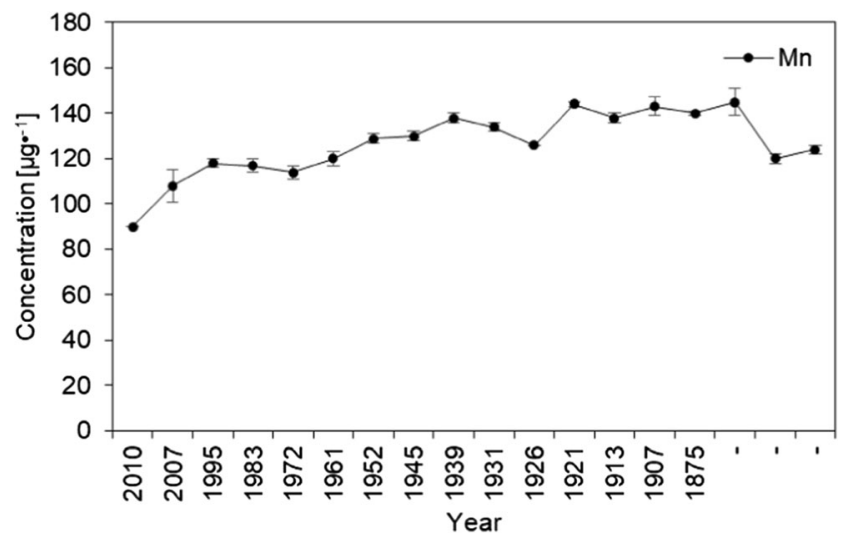

Fig. 10 Changes of manganese concentration in the sediments core of the Mały Staw Lake
Generally, Karkonosze Mts. ridge is built of Paleozoic granitic rocks and slate metamorphic rocks. It causes that the soils of Karkonosze reveal fragmentary characteristic of specific properties. $\mathrm{pH}$ of the Karkonosze soils is acidic, below 5.0 with the lowest values of 3.5, which is their genetic property and only to a little extend it is influenced by pollution of the region (acid rains) (Skiba 1995). For the sorptive properties of the prevailing in Karkonosze mineral soils, considering small amount of clay minerals in the soils, mainly carious material is responsible (Kabala 2011). Both these factors cause that metals delivered to the soil in the result of industrial pollution (which can be attributed to the so called "screen effect of mountainous systems") can easily migrate between the environment components (soil, water, sediments). Taking this into account and comparing the obtained results with data reporting concentration of heavy metals in the surface layers of soils of the Karkonosze (Skiba et al. 1994; Skiba 1995), meaningful similarities to the sediments' compositions can be found. For the Snieżka massif, concentrations of $\mathrm{Cr}, \mathrm{Cu}, \mathrm{Pb}$, and $\mathrm{Zn}$ were in the same order of magnitude as determined in the sediments of the Mały Staw Lake (Table 5). These were as follows (ranges of concentrations in $\mathrm{mg} \mathrm{kg}^{-1}$ ): $\mathrm{Cd} 1.69-3.88$; Cr 6.94-22.3; Cu 6.54-38.19; Pb 91.4-312.5; Zn 12.4-94.5 (Skiba et al. 1994). This fact proves mobility of the elements

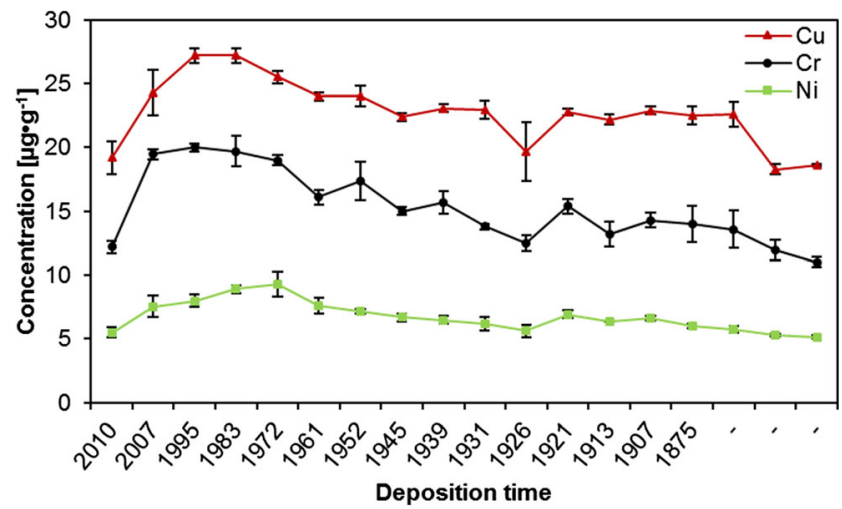

Fig. 11 Changes of copper, chromium, and nickel concentrations in the sediments core of the Mały Staw Lake 


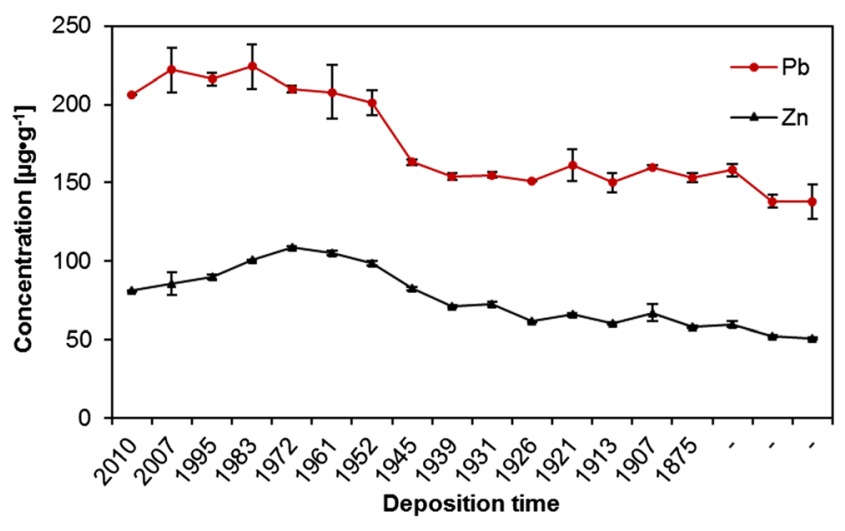

Fig. 12 Changes of lead and zinc concentrations in the sediments core of the Mały Staw Lake

resulting from their chemical properties (for example $\mathrm{Cd}$ and $\mathrm{Zn}$ ), and/or mobility with the sorbent (elements adsorbed by carious material- $\mathrm{Pb}, \mathrm{Cu}, \mathrm{Ni}, \mathrm{Cd}$ ) (Binczycki et al. 2015).

The obtained quantitative data can be discussed basing on the use of certain chemometric tools, enabling multidimensional analysis. To extract meaningful relationships between the analyzed objects (sediments' core layers) and variables (elements concentrations), cluster analysis (CA) and principal components analysis (PCA) were chosen. All elements concentrations values were standardized prior to chemometric analysis. Considering groups of the elements (Fig. 9), two main clusters can be distinguished. The first one, marked with the green oval, consists of $\mathrm{Fe}, \mathrm{Mn}, \mathrm{Mg}$, and $\mathrm{K}$ - the elements which are present in the soil and rocks of Karkonosze naturally and in relatively high concentrations (Skiba et al. 1994; Skiba 1995; Binczycki et al. 2015). Their changes in the core are similar and may be influenced mainly by the natural climatic and weathering processes. Human activity has lesser influence on the elements transport and accumulation in the sediments in time. All four elements are characterized by small concentration variability and similar course of changes (with the exception of the first, top sediments layer) (Table 3 and Fig. 10). The second main cluster (marked with the red oval) (Fig. 9) consists of trace metals and sodium. In this cluster, two sub-clusters are visible.
One, consisting of $\mathrm{Cr}, \mathrm{Ni}, \mathrm{Cu}$, and $\mathrm{Na}$, represents elements showing almost constant increasing tendency of the elements' concentrations in time (Fig. 11), while the second sub-cluster (consisting of $\mathrm{Pb}, \mathrm{Cd}$, and $\mathrm{Zn}$ ) is characterized by slight different course of the elements concentration changes - initial low concentration in the deep sediments layers, substantial increase in the layers dated back to the second half of the twentieth century, and decrease of concentrations in recent years (Fig. 12). Definitely, this increase of the elements concentrations results from human industrial activity in the discussed area but also results from the deposition of pollutants transported in the atmosphere to the long distances and as a result of acidity of the Karkonosze soils, promoting washing out of the adsorbed elements from the soil surrounding the lake. The Karkonosze Mts. form the natural barrier for the wind. Air masses predominantly (75\%) flow from the industrialized regions of the Czech Republic (Most-Teplice), Germany (Cottbus), and Poland (Turoszów, Gubin, Jelenia Góra). They are characterized by the elevated levels of heavy metals content, and due to dry and wet deposition are the source of soil and water contamination in the region.

The decrease of the elements concentrations in the twentyfirst century is a direct result of introduction of new measures of environment protection in Europe and Poland. It is worth to notice that considering concentrations of $\mathrm{Cr}, \mathrm{Cu}$, and $\mathrm{Ni}$ in the sediments, their current level (in the top layer of the sediments) is comparable to the level found in the deepest layers, what suggests that currently their concentration is mainly influenced by the natural processes. On the other hand, concentrations of $\mathrm{Pb}, \mathrm{Cd}$, and $\mathrm{Zn}$ are still substantially higher in the younger layers than in the old ones - these elements are constantly delivered to the environment of the Mały Staw Lake (Fig. 12).

It is worth to add that increasing touristic activity could influence quality of the sediments (Mierzejewski 2005).

Considering the similarity of the studied objects (sediments' layers in the core), two clusters are clearly distinguished, i.e., the first covering the samples deposited in years after the Second World War till present, and the second cluster containing older samples (Fig. 13). It is also evident that such
Fig. 13 Dendrogram presenting similarity of the sediments layers in the core of the Mały Staw Lake

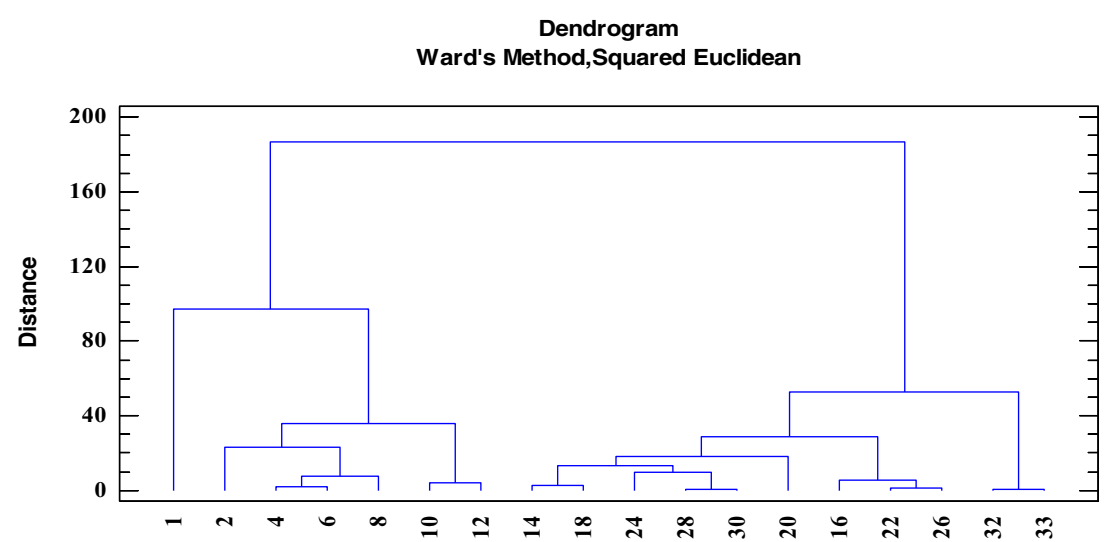


division is a consequence of anthropogenic influence on the environment with the predominant influence of long-distance transport of pollutants. In the top layer of the sediments (Fig. 13 and Table 2), concentrations of the elements are substantially lower than in the adjacent layer 2 . This may result from the current exchange equilibrium between the elements concentrations in the sediments and in the water body.

\section{Conclusions}

The Mały Staw Lake is a cirque, post-glacial lake with welldocumented history of natural and anthropogenic factors that influence of sediment' properties. We proved that the comprehensive approach of the sediments' studies, based on analyti$\mathrm{cal}$, radiochemical, sedimentological, and geomorphological methods, confirmed environmental changes in the studied area. Based on CRS model, using ${ }^{210} \mathrm{~Pb}$ dating, we analyzed a $28-\mathrm{cm}$-long sediment core representing the last ca 138 years. The dating results were confirmed by ${ }^{137} \mathrm{Cs}$ studies. All analytical results were presented in a time scale. For the first time, in respect to the sediments of the Mały Staw Lake, such approach was proposed and executed.

Basing on the results achieved in this study, the following could be concluded:

1. The bathymetry map has provided valuable insights into the nature and distribution of the sediments. It was also helpful in choosing the representative sampling points for the studied area;

2. Łomnica river and fans deposits deliver the solid material to the lake;

3. The causes of elevated values of sedimentation rates are a sudden huge supply materials from slopes during storm water or avalanches;

4. Taking into account the level of heavy metals concentration, the sediments were classified according to the Bojakowska scale of sediments contamination;

5. Based on historical sources and chemometric analysis, the metals' origin were indicated and confirmed.

To summarize, the proposed research approach can be successfully applied to natural and also man-made water reservoirs studies. Particularly valuable information can be drawn with regard to man-made reservoir located in the past mining region. Furthermore, collecting information and analysis of similar records from other similar lakes in different areas of the globe could afford valuable evidence in attempt to produce more general assessment of sediments' sensitivity to environmental changes.

Acknowledgments The authors would like to thank the administration of the Karkonoski National Park for their help in sediments sampling.
Funding information This work was supported by the AGH University of Science and Technology Grant No 11.11.210.374.

Open Access This article is distributed under the terms of the Creative Commons Attribution 4.0 International License (http:// creativecommons.org/licenses/by/4.0/), which permits unrestricted use, distribution, and reproduction in any medium, provided you give appropriate credit to the original author(s) and the source, provide a link to the Creative Commons license, and indicate if changes were made.

\section{References}

Appleby PG (2001) Chronostratigraphic techniques in recent sediments. In: Last WM, Smol JP (eds) Tracking environmental change using lake sediments volume 1: basin analysis, coring, and chronological techniques. Kluwer Academic Publishers, Dordrecht, pp 171-203

Appleby PG (2008) Three decades of dating recent sediments by fallout radionuclides: a review. The Holocene 18(1):83-93. https://doi.org/ 10.1177/0959683607085598

Appleby PG, Oldfield F (1978) The calculation of lead-210 dates assuming a constant rate of supply of unsupported ${ }^{210} \mathrm{~Pb}$ to the sediment. Catena 5(1):1-8. https://doi.org/10.1016/S0341-8162(78)80002-2

Aycik GA, Cetaku D, Erten HN, Salihoglu I (2004) Dating of Black Sea sediments from Romanian coast using natural ${ }^{210} \mathrm{~Pb}$ and fallout ${ }^{137}$ Cs. J Radioanal Nucl Chem 259(1):177-180. https://doi.org/10. 1023/B:JRNC.0000015825.67418.18

Biernacka M, Lipinski P, Sosinska A (2004) Radioactive contamination of soil and background gamma radiation in Poland, 1988-2001. Inspection of Environmental Protection, Warszawa (in Polish)

Binczycki T, Kocowicz A, Tyszka R, Weber J (2015) The anthropogenic influence on content and forms of heavy metals in Giant Mountains' soils in respect to the results of research conducted in recent decades. KPN, Jelenia Gora (in Polish)

Bitusík P, Kubovcík V, Stefkova E, Appleby PG, Svitok M (2009) Subfossil diatoms and chironomids along an altitudinal gradient in the High Tatra Mountain lakes: a multi-proxy record of past environmental trends. Hydrobiologia 631(1):65-85. https://doi.org/10. 1007/s10750-009-9802-0

Bojakowska I, Sokolowska G (1998) Geochemical sediments quality classes. Geological review 46(1):49-54 (in Polish)

Central Statistical Office (2008) Concise statistical year book of Poland. Statistical Publishing Establishment, Warsaw

Central Statistical Office (2009) Concise statistical year book of Poland. Statistical Publishing Establishment, Warsaw

Central Statistical Office (2010) Concise statistical year book of Poland. Statistical Publishing Establishment, Warsaw

Central Statistical Office (2011) Concise statistical year book of Poland. Statistical Publishing Establishment, Warsaw

Czerwinski J (1995) High altitude meteorological observatory on Sniezka. Publishing House of National Environmental Protection Agency, Wroclaw (in Polish)

de Deckere E, De Cooman W, Leloup V, Meire P, Schmitt C, von der Ohe PC (2011) Development of sediment quality guidelines for freshwater ecosystems. J Soils Sediments 11(3):504-517. https://doi.org/10. 1007/s11368-010-0328-x

Dube A, Zbytniewski R, Kowalkowski T, Cukrowska E, Buszewski B (2001) Adsorption and migration of heavy metals in soils. Pol J Environ Stud 10(1):1-10

Flynn WW (1968) The determination of low levels of polonium-210 in environmental materials. Anal Chim Acta 43(2):221-227. https:// doi.org/10.1016/S0003-2670(00)89210-7 
Grba N, Krcmar D, Maletic S et al (2016) Organic and inorganic priority substances in sediments of Ludas Lake, a cross-border natural resource on the Ramsar list. Environ Sci Pollut Res 24(2):1938-1952. https://doi.org/10.1007/s11356-016-7904-6

Guzman G, Quinton JN, Nearing MA, Mabit L, Gomez JA (2013) Sediment tracers in water erosion studies: current approaches and challenges. J Soils Sediments 13(4):816-833. https://doi.org/10. 1007/s11368-013-0659-5

Hamerlík L, Dobríkova D, Szarlowicz K et al (2016) Lake biota response to human impact and local climate during the last 200 years: a multiproxy study of a subalpine lake (Tatra Mountains, W Carpathians). Sci Total Environ 545-546:320-328. https://doi.org/10.1016/j. scitotenv.2015.12.049

Isajenko K, Piotrowska B, Fujak M, Kardas M (2012) Radiation atlas of Poland 2011. Inspection of Environmental Protection, Warszawa (in Polish)

Jahn A (1985) Polish Giant Mountains. Polish Academy of Science PAN, Wroclaw (in Polish)

Kabala C (2011) Soils of the Giant Mountains. In: Knapik R, Przewoznik L, Raj A (eds) 50 years of scientific investigation in the Giant Mountains National Park. KPN, Jelenia Gora, pp 105-126 (in Polish)

Kardas M, Rosiak L, Fulara A, Podstawka D, Adamczyk A (2011) Monitoring of radioactive contamination of surface waters and bottom sediments. In: Krajewski P (ed) Activity report year 2011. Central Laboratory for Radiological Protection, Warszawa, pp 1112 (in Polish)

Klaminder J, Appleby P, Crook P, Renberg I (2012) Post-deposition diffusion of ${ }^{137} \mathrm{Cs}$ in lake sediment: implications for radiocaesium dating. Sedimentology 59(7):2259-2267. https://doi.org/10.1111/j. 1365-3091.2012.01343.x

Komar T (1949) Maly Staw Lake and Wielki Staw Lake in Giant Mountains. In: Goetel W (ed) Wierchy. PTT, Krakow, p 57 (in Polish)

Last WM, Smol JP (eds) (2001) Tracking environmental change using lake sediments, volume 2: physical and geochemical methods. Kluwer Academic Publishers, London. https://doi.org/10.1007/0306-47669-X

Lofrano G, Libralato G, Minetto D, de Gisi S, Todaro F, Conte B, Calabrò D, Quatraro L, Notarnicola M (2016) In situ remediation of contaminated marine sediment: an overview. Environ Sci Pollut Res 24(6): 5189-5206. https://doi.org/10.1007/s11356-016-8281-x

Ma L, Wu J, Abuduwaili J (2013) Climate and environmental changes over the past 150 years inferred from the sediments of Chaiwopu Lake, central Tianshan Mountains, northwest China. Int J Earth Sci 102(3):959-967. https://doi.org/10.1007/s00531-012-0838-4

McCall PL, Robbins JA, Matisoff G (1984) ${ }^{137} \mathrm{Cs}$ and ${ }^{210} \mathrm{~Pb}$ transport and geochronologies in urbanized reservoirs with rapidly increasing sedimentation rates. Chem Geol 44(1-3):33-65. https://doi.org/10. 1016/0009-2541(84)90066-4

Mierzejewski MP (2005) Giant Mountains. Inanimate nature and human. Wroclaw University Press, Wroclaw (in Polish)
Misiak R, Hajduk R, Stobinski M, Bartyzel M, Szarlowicz K, Kubica B (2011) Self-absorption correction and efficiency calibration for radioactivity measurement of environmental samples by gamma-ray spectrometry. Nukleonika 56(1):23-28

Noges P, Tuvikene L, Noges T, Kisand A (1999) Primary production, sedimentation and resuspension in large shallow Lake Vortsjarv. Aquat Sci 61(2):168-182. https://doi.org/10.1007/PL 00001323

Parzoch K, Migon P, Szymanowski R, Gasiorek M (2007) Debris flows in the northern part of the Giant Mountains. Opera Corcontica 44(1): 81-88 (in Polish)

Piasecki H (1958) Maly Staw Lake in Giant Mountains as an example of tarn, moraine dammed lake. Geogr Mag 29(1):75-78 (in Polish)

Ritchie JC, McHenry JR (1990) Application of radioactive fallout cesium-137 for measuring soil erosion and sediments accumulation rates and patterns: a review. J Environ Qual 19(2):215-233. https:// doi.org/10.2134/jeq1990.00472425001900020006x

Sandor Z, Csengeril I, Oncsik MB, Alexis MN, Zubcova E (2001) Trace metal levels in freshwater fish, sediment and water. Environ Sci Pollut R 8(4):265-268. https://doi.org/10.1007/BF02987404

Sienkiewicz E, Gasiorowski M, Hercman H (2006) Is acid rain impacting the Sudetic lakes? Sci Total Environ 369(1-3):139-149. https://doi. org/10.1016/j.scitotenv.2006.05.001

Skiba S (1995) Evaluation of the impact of industrial emissions on the soil of the Giant Mountains. In: Fischer Z (ed) Ecological problems of high mountain part of Giant Mountains. Publishing House of the Institute of Ecology PAN, Dziekanow Lesny, pp 97-111 (in Polish)

Skiba S, Drewnik M, Szmuc R (1994) Heavy metals in soils taken from selected areas of Giant Mountains. In: Fisher Z (ed) Giant Mountains Ecological Studies. Publishing House of the Institute of Ecology PAN, Dziekanow Lesny, pp 125-134 (in Polish)

Smol JP, Walker IR, Leavitt PR (1991) IV. Paleolimnology: Paleolimnology and hindcasting climatic trends. Verh Internat Verein Limnol 24:1240-1246

Szarlowicz K, Reczynski W, Misiak R, Kubica B (2013) Radionuclides and heavy metal concentrations as complementary tools for studying the impact of industrialization on the environment. J Radioanal Nucl Chem 298(2):1323-1333. https://doi.org/10.1007/s10967-013-2548-1

Szczepanska A, Zaborska A, Maciejewska A, Kulinski K, Pempkowiak J (2012) Distribution and origin of organic matter in the Baltic sea sediments dated with ${ }^{210} \mathrm{~Pb}$ and ${ }^{137} \mathrm{Cs}$. Geochronometria 39(1):1-9. https://doi.org/10.2478/s13386-011-0058-x

Teuchies J, Bervoets L, Meynendonckx J, Meire P, de Deckere E (2011) The effect of waste water treatment on river metal concentrations: removal or enrichment. J Soils Sediments 11(2):364-372. https:// doi.org/10.1007/s11368-010-0321-4

UNSCEAR (2000) Sources effects and risks of ionizing radiation. United Nations Scientific Committee on the effects of atomic radiation, report to the general assembly, with annexes. United Nation, New York

Walling DE, He Q (1992) Interpretation of caesium-137 profiles in lacustrine and other sediments: the role of the catchment-derived inputs. Hydrobiologia 235(1):219-230. https://doi.org/10.1007/ BF00026214 